MACIEJ PIETRZAK

Instytut Filmu, Mediów i Sztuk Audiowizualnych Uniwersytet im. Adama Mickiewicza w Poznaniu
Images vol. XXVI/no. 35

Poznań 2019

ISSN 1731-45OX

\title{
Uśpiony temat. O (nie)obecności problemu Marca 1968 roku $w$ kinie dokumentalnym okresu PRL
}

\begin{abstract}
Pietrzak Maciej, Uśpiony temat. O (nie)obecności problemu Marca 1968 roku w kinie dokumentalnym okresu PRL [Dormant topic. About the absence of the events of March 1968 in Polish documentary films before 1989]. „Images” vol. XXVI, no 35. Poznań 2019. Adam Mickiewicz University Press. Pp. 63-75. ISSN 1731-450X. DOI 10.14746/i.2019.35.03.

The vast majority of documentary films relevant to the events of March ' 68 and its consequences were created after 1989, when the abolition of censorship and the opening of previously hidden archives allowed Polish filmmakers to explore previously prohibited topics. The article focuses on the earlier period, and its main objective is to find echos of this political crisis in documentary films created before the collapse of the communist regime in Poland.
\end{abstract}

KEYwORDs: March ‘68, Polish documentary films, film and politics, film and propaganda

Wydarzenia Marca 1968 roku mają dziś bogatą dokumentalną filmografię, na którą składają się dziesiątki filmów skoncentrowanych na różnych aspektach politycznego kryzysu, który wstrząsnął Polską Ludową w schyłkowym okresie rządów Władysława Gomułki. Znajdziemy wśród nich między innymi produkcje rekonstruujące przebieg pacyfikacji studenckich manifestacji[1], obrazy opowiadające o politycznym dojrzewaniu młodych aktywistów tamtego czasu[2], dokumenty poświęcone problemowi pomarcowego exodusu ludności pochodzenia żydowskiego [3] czy biograficzne portrety ofiar ówczesnej „antysyjonistycznej” i antyinteligenckiej nagonki[4]. Ważny element wspomnianego zbioru stanowią również zrealizowane na Zachodzie filmy pomarcowego emigranta Mariana Marzyńskiego[5].

Nietrudno dostrzec, iż zdecydowana większość filmów dokumentalnych poruszających temat Marca '68 i jego następstw powstała

[1] Marzec '68 w obiektywie MSW, reż. J. Eisler, M. Maldis, 1993; Marzec '68. Milicyjny zapis, reż. P. Morawski, 2001; Taśmy Marca, reż. J. Sawicki, 2008. [2] I naprawdę nie wiedzieliśmy, reż. A. Titkow, 1993; Iskra w kamieniu, reż. M. Muzyczuk, A. Chwalba, L. Ptaszyński, 2007; Zwyczajny Marzec, reż. M. Zmarz-Koczanowicz, 2008.

[3] Siedmiu Żydów z mojej klasy, reż. M. Łoziński, 1991; Pociag do Wiednia, reż. A.M. Drążewski, 1998; Dworzec Gdański, reż. M. Zmarz-Koczanowicz, 2007.
[4] Dejmek, reż. I. Szczepański, 2002; Polska Jasienicy, reż. R. Mierzejewski, 2009; Bossak. Kronika wypadków filmowych, reż. M. Burzyńska-Keller, 2010. [5] Więcej o „marcowych” wątkach w twórczości Marzyńskiego zob. M. Pietrzak, Wygnanie ocalonych. Doświadczenie emigracji pomarcowej w filmach Mariana Marzyńskiego i Leszka Leo Kantora, „Images. The International Journal of European Film, Performing Arts and Audiovisual Communication" 2017, nr 29, s. 137-147. 
już po roku 1989. Zniesienie cenzuralnych restrykcji i otwarcie niedostępnych dotąd archiwów pozwoliło bowiem filmowcom na eksplorację zakazanych uprzednio tematów, wśród których znajdowały się także wydarzenia roku 1968. W niniejszym tekście skupię się jednak na okresie wcześniejszym i postaram się prześledzić nieliczne echa marcowego kryzysu, które odnaleźć możemy w szeroko rozumianym kinie dokumentalnym okresu PRL.

\title{
Ofiary i koniunkturaliści
}

Środowisko polskich dokumentalistów szczególnie mocno odczuło konsekwencje wypadków marcowych. Od samego początku wymierzonej w kinematografię kampanii propagandowej jednym z głównych obiektów ataków personalnych był Jerzy Bossak. Niedługo później klasyk powojennego dokumentu został wyrzucony ze wszystkich zajmowanych stanowisk (między innymi z posady kierownika artystycznego WFD), utracił też możliwość realizacji filmów, co było początkiem końca jego reżyserskiej kariery. Trwająca wiele tygodni antysemicka nagonka przyczyniła się również do emigracji wielu wybitnych dokumentalistów, którzy, pozbawieni możliwości pracy w rodzinnym kraju, podejmowali niełatwą decyzję o wyjeździe na Zachód. Polskę na długie lata opuścili wówczas między innymi Tadeusz Jaworski, Władysław Forbert, Edward Etler, wspomniany wyżej Marian Marzyński[6] oraz wieloletnia redaktor naczelna Polskiej Kroniki Filmowej Helena Lemańska[7].

Podczas gdy jedni przedstawiciele środowiska dotkliwie doświadczyli skutków „antysyjonistycznego” wzmożenia, inni jego reprezentanci aktywnie angażowali się w kampanijną ofensywę władz. Architekci marcowej nagonki zaplanowali bowiem dla dokumentu ważne miejsce w rozpędzonej machinie propagandowej. Oczekiwania, jakie kierowano wówczas pod adresem filmu dokumentalnego, sugestywnie wyraziła w kwietniu 1968 roku Alicja Iskierko w rozmowie z ówczesnym kierownikiem redakcji WFD Henrykiem Jantosem:

\begin{abstract}
Ostatnie tygodnie charakteryzują się wzmożonym zapotrzebowaniem na informację, fakt niezbędny, toczącej się tak intensywnie ogólnonarodowej dyskusji. Nasz dokument filmowy dzięki swemu wysokiemu poziomowi i ideowemu zaangażowaniu zaskarbił sobie powszechne uznanie widzów, co wskazują między innymi wyniki badań naukowych. Mamy nadzieję, iż aktualne zamierzenia programowe Wytwórni Filmów Dokumentalnych uwzględniają podjęcie tematów znajdujących się obecnie w centrum społecznej uwagi...[8]
\end{abstract}

[6] M. Jazdon, P. Pławuszewski, Polski film dokumentalny lat siedemdziesiatych. Nic o nas bez nas, [w:] Historia polskiego filmu dokumentalnego (1945-2014), red. M. Hendrykowska, Poznań 2015, s. 230-231. [7] Lemańska straciła stanowisko już w roku 1967 na skutek odmowy udziału w rozpoczynającej się wówczas kampanii antysyjonistycznej. - Ł. Jędrzejski, Pol- ska Kronika Filmowa w latach 1945-1968 jako medium partyjne. Zarys problemu, „Polityka i Społeczeństwo” 2017, nr 1, s. 167-168.

[8] A. Iskierko, Poszukiwanie prawdy o przeszłości i dniu dzisiejszym w Wytwórni Filmów Dokumentalnych. Wywiad z H. Jantosem, „Ekran” 1968, nr 18, s. 11. 
Zapotrzebowanie na utwór wspierający oficjalny przekaz o syjonistycznym spisku wymierzonym w dobre imię PRL zostało zaspokojone w tempie niemalże ekspresowym. Już w pierwszych tygodniach kwietnia w szeregu ogólnopolskich czasopism pojawiły się informacje o realizowanym przez Janusza Kidawę - na podstawie scenariusza napisanego wspólnie z Ryszardem Gontarzem - filmie Sprawiedliwi, który opowiadać miał o bohaterskiej postawie Polaków ratujących Żydów w czasie II wojny światowej. Przez kilka miesięcy prasa na bieżąco informowała o postępach w produkcji, zachęcając jednocześnie do nadsyłania twórcom wszelkich materiałów i osobistych świadectw związanych z podjętym przez nich tematem[9]. Propagandowy cel przyświecający realizacji Sprawiedliwych w jednym z prasowych doniesień wymownie określił sam reżyser:

Film taki powinien już dawno powstać. Codziennie docierają do nas echa oszczerczej kampanii rozpętanej na Zachodzie przez wrogie Polsce ośrodki syjonistyczne. Dedykujemy ten film tym wszystkim Polakom, którzy nieśli pomoc Żydom, a o ich ofiarności i poświęceniu często niewiele lub też nic nie wiemy...[10]

Główną dominantą ukończonego w lecie 1968 roku filmu było podkreślenie masowego charakteru pomocy udzielanej Żydom przez ich polskich współobywateli. Przedstawioną w Sprawiedliwych wersję historii oparto na przekonaniu o identyczności wojennej sytuacji obu społeczności. W wizji tej Holocaust to jedynie część większego planu, którego celem była eksterminacja całego narodu polskiego[11]. Ukazanie symetrii cierpienia posłużyło twórcom za punkt wyjścia do wyartykułowania utrzymanych w duchu marcowej propagandy zarzutów, w filmie uderza bowiem kontrast pomiędzy akcentowaną wielokrotnie bohaterską postawą Polaków i powracającymi oskarżeniami o żydowską bezczynność, a nawet kolaborację z okupantem. Wątek ten dobrze ilustruje wypowiedź Ryszarda Gontarza udzielona telewizyjnej Kronice Kulturalnej w okresie realizacji filmu:

Niosąc pomoc Żydom, natykaliśmy nie tylko na terror okupanta, ale także na jakąś niesłychaną bierność mas żydowskich i na przeciwdziałanie różnych ośrodków żydowskich. Mam na myśli tutaj policję żydowską, judenraty, gestapo żydowskie. [...] Z tymi ośrodkami kolaboracji musieliśmy walczyć, niosąc pomoc.

Co ważne, w finale utworu lista oskarżonych została wzbogacona również o "rozsianych po świecie bogatych i wpływowych współbraci” mordowanych Żydów, którzy w czasie Zagłady „nie zdobyli się na nic

[9] Teksty poświęcone powstającemu filmowi publikowały między innymi „Magazyn Filmowy”; „Film” i „Ekran”: Zamierzenia i plany WFD, „Magazyn Filmowy” 1968, nr 20, s. 2; Sprawiedliwi, „Film” 1968, nr 16, s. 2; "Sprawiedliwi” i inne filmy dokumentalne, „Film” 1968, nr 20, s. 2; Dobiega końca realizacja „Sprawiedliwych”, „Magazyn Filmowy” 1968, nr 26, s. 15; J. Kidawa, Sprawiedliwi. Świadectwo prawdy o dawnych czasach. Rozm. przepr. K. Zybert, „Ekran” 1968, nr 16, s. 2.

[10] J. Kidawa, Sprawiedliwi, „Magazyn Filmowy”, 1968 nr 16, s. 15.

[11] T. Żukowski, Fantazmat „Sprawiedliwych” i film „W ciemności” Agnieszki Holland, „Studia Litteraria et Historica" 2012, $\mathrm{nr}$ 1, s. 2. 
prócz wyrazów współczucia”. Także uratowani z ludobójstwa okazali się niepozbawieni winy, gdyż zapomnieli o swoich wybawcach i włączyli się w syjonistyczną kampanię zniesławienia Polaków. Pokrewny wydźwięk miał poświęcony obchodom 25 rocznicy powstania w getcie warszawskim dokument Romana Wionczka O tym nie wolno zapomnieć. Podobnie jak w przypadku Sprawiedliwych, w filmie niejednokrotnie podkreślano powszechną ofiarność Polaków wobec żydowskiej tragedii, której miała towarzyszyć domniemana obojętność wpływowych kół żydowskich na Zachodzie[12]. W obu filmach zmanipulowana wersja historii służyła zatem uwiarygodnieniu oficjalnej narracji, według której za społeczne niepokoje targające krajem odpowiedzialne były potężne imperialistyczno-syjonistyczne siły wrogie Polsce Ludowej[13].

\section{Lakoniczna PKF}

Przynależne jej zadania propagandowe wypełniała w tym czasie również Polska Kronika Filmowa, która już od czerwca 1967 roku aktywnie uczestniczyła w kampanii antysyjonistycznej, cyklicznie publikując materiały poświęcone izraelsko-arabskiemu konfliktowi na Bliskim Wschodzie[14]. Burzliwe wydarzenia wiosny 1968 roku zostały jednak potraktowane przez redaktorów Kroniki nad wyraz oszczędnie. Cenzuralne restrykcje uniemożliwiły między innymi publikację zarejestrowanych przez operatorów PKF zdjęć przedstawiających manifestacje warszawskich studentów. Najbardziej bezpośrednim odniesieniem do wypadków marcowych w ówczesnych wydaniach Kroniki była natomiast relacja ze spotkania pierwszego sekretarza PZPR ze stołecznym aktywem partyjnym z 19 marca 1968 roku (PKF 12B/68)[15]. Krótki fragment wystąpienia towarzysza Wiesława, w którym przywódca rozprawiał nad zmanipulowaniem demonstrującej młodzieży przez siły wrogie socjalizmowi, spuentowano jedynie zdawkowym komentarzem:

Przemówienie Władysława Gomułki było dla całego społeczeństwa polskiego głosem rozsądku i odpowiedzialności politycznej, otwierając drogę do dalszej szczerej dyskusji na płaszczyźnie patriotyzmu i socjalizmu.

Jedno z kwietniowych wydań (PKF 16A/68) przyniosło z kolei szczątkową relację z sejmowej dyskusji nad słynną interpelacją koła „Znak” w obronie represjonowanych studentów. W materiale nie pojawiły się jednak żadne informacje na temat treści poselskiego zapytania, całkowicie pominięto również pamiętne wystąpienie Jerzego Zawieyskiego. Widzowie mogli obejrzeć jedynie krótki fragment przemówienia premiera Józefa Cyrankiewicza, które - podobnie jak

[12] O tym nie wolno zapomnieć, „Magazyn Filmowy” 1968, nr 31, s. 10.

[13] Warto nadmienić, iż w 1968 roku Kidawa i Gontarz zrealizowali również krótkometrażowy film Cena życia i śmierci, który - podobnie jak Sprawiedliwi - poświęcony był pomocy udzielanej ludności żydowskiej przez Polaków w czasie II wojny światowej. Obraz ten został jednak zatrzymany przez cenzurę. - P. Zwierzchowski, Rok 1968 w polskim kinie - konteksty i konsekwencje, [w:] Yesterday. Studia $z$ historii najnowszej. Ksiega dedykowana prof. Jerzemu Eislerowi $w$ 65. rocznice urodzin, red. J. Olaszek i in., Warszawa 2017, s. 609.

[14] M.K. Cieśliński, Piękniej niż w życiu. Polska Kronika Filmowa 1944-1994, Warszawa 2006, s. 109.

[15] Ibidem, s. 110. 
przywołana wcześniej mowa pierwszego sekretarza - podsumowane zostało bardzo oszczędnie:

Premier omówił tło i przyczyny ostatnich wydarzeń w kraju i potępił tych, którzy je chcieli wykorzystać przeciw państwu ludowemu. Wiele spraw wewnętrznych w Polsce wymagać będzie analizy i poprawy.

W kolejnym tygodniu Kronika donosiła o wzmożonym napływie młodych ludzi do struktur partyjnych (PKF 17B/68). Podkreślano, iż na zebraniach i konferencjach środowiskowych w całym kraju wyrażają oni gorące poparcie dla obecnej polityki władz. Materiał zilustrowano zdjęciami przedstawiającymi uroczystość przyjęcia do PZPR wyraźnie uszczęśliwionych tym faktem działaczy Związku Młodzieży Socjalistycznej. Głos lektora informował:

Wydarzenia minionych tygodni w naszym życiu politycznym przyspieszyły kształtowanie się postaw światopoglądowych i społecznego zaangażowania. W szeregi partyjne wstępują nowi członkowie. Działacze ZMS otrzymują legitymacje kandydackie. Procesowi oczyszczania partii z ludzi obcych jej zasadom ideowym towarzyszy rozwój organizacji partyjnych we wszystkich środowiskach zawodowych.

Podobny wydźwięk miało też jedno z lipcowych wydań (PKF 28B/68), które w materiale poświęconym inauguracji egzaminów na studia wyższe zapewniało, iż „studenckie niepokoje, które przeszły przez kraj, nie przysłoniły faktu, że najważniejszą sprawą jest nauka i dostęp do nauki”.

Co znamienne, żaden z filmów dokumentalnych zrealizowanych w końcu lat sześćdziesiątych nie zarejestrował nawet najsubtelniejszych sygnałów studenckich wystąpień; dokumentaliści całkowicie przemilczeli również kwestię exodusu obywateli pochodzenia żydowskiego. Kuratela rządzących nad produkcją filmową w tym obszarze okazała się zatem niezwykle efektywna. Esencjonalnie sytuację tę scharakteryzowała Jolanta Lemann, pisząc, iż: „Wydarzeń marcowych 1968 r. film dokumentalny nie zauważył. Autocenzura i cenzura przyniosły spodziewane rezultaty"[16]. Przyczyny tego stanu rzeczy wydają się jednak bardziej skomplikowane. Próbom zawoalowanego nawiązania do aktualnych wydarzeń politycznych nie sprzyjały bowiem również przyjęte ówcześnie modele opowiadania filmowego.

Swoje ograniczenia w zakresie odwzorowywania ówczesnych nastrojów społecznych ujawniła wówczas między innymi oparta na wnikliwej obserwacji wybranego wycinka rzeczywistości metoda twórcza Kazimierza Karabasza. Zrealizowany przez niego w 1967 roku, obsypany nagrodami film Rok Franka W., mimo iż koncentrował się na losach wchodzącego w dorosłość dwudziestolatka, w najmniejszym stopniu

[16] J. Lemann, Film dokumentalny, [w:] Encyklopedia kultury polskiej XX wieku. Film - kinematografia, red.

E. Zajiček, Warszawa 1994, s. 232.

\section{Ograniczenia cierpliwego oka}


nie zapowiadał nadchodzącej erupcji młodzieżowych niepokojów. Jak pisał Tadeusz Lubelski:

Artystyczna odkrywczość filmu nie mogła jednak przesłonić faktu, że kiedy w kwietniu 1968 roku wszedł on na ekrany - spokojne, życzliwie obiektywne stanowisko autora brzmiało jak polityczny unik; Ochotnicze Hufce Pracy zaczęły się kojarzyć z wymierzonymi w studentów represjami[17].

Oznak społecznego wzburzenia nie zarejestrował też kolejny film Karabasza, w którym twórca Muzykantów rozwijał zapoczątkowaną Rokiem Franka W. serię dokumentalnych portretów przedstawicieli młodego pokolenia. Powstająca na przestrzeni niemal dwóch lat Sobota Grażyny A. i Jerzego T. (1969) nie odnotowała symptomów społecznego fermentu charakteryzującego ostatnie lata rządów Władysława Gomułki. Obrazowo ten niedostatek utworu opisał Stanisław Ozimek:

Autorzy filmu, mimo długiego okresu jego realizacji, zdawali się nie dostrzegać lub chociażby antycypować ówczesnych nastrojów, które zaczęły kumulować się np. w młodzieżowo-studenckich protestach Marca 1968. Nie znalazły one nawet pogłosu czy repliki w „Sobocie Grażyny A. i Jerzego T.” Prezentowana przez Karabasza sonda socjologiczna nie uchwyciła sygnałów „rozedrganego sejsmografu ówczesnej rzeczywistości”[18].

Ten stan rzeczy nie mógł zaskakiwać, ponieważ filmy Karabasza i jego naśladowców programowo nie eksplorowały obszarów rzeczywistości związanych z polityką. Poza kręgiem ich zainteresowania pozostawały też wszelkie próby opisu napiętej sytuacji społecznej tamtego czasu[19]. Przyjęta przez rzeczonych twórców poetyka lirycznej obserwacji życia, która w latach sześćdziesiątych obrodziła mnogością wybitnych dzieł, stanowiących o wyjątkowej pozycji polskiego dokumentu, po kryzysowych doświadczeniach z lat 1968-1970 spotkała się jednak z zarzutami o celowe pomijanie trudnych tematów.

\section{Głos marcowego pokolenia}

Najdonioślejszym wyrazem tej krytyki był głośny „bunt dokumentalistów" objawiony podczas Ogólnopolskiego Festiwalu Filmów Krótkometrażowych w Krakowie w 1971 roku. W trakcie imprezy swoją obecność zamanifestowała silna grupa młodych reżyserów, otwarcie kontestujących metody twórcze klasyków polskiego dokumentu. Prócz rewolucyjnych haseł spoiwem powstającej formacji - z czasem okrzykniętej mianem „nowej zmiany” bądź „szkoły krakowskiej” - była bez wątpienia wspólnota pokoleniowych doświadczeń. Dokumentaliści stanowiący trzon grupy, na czele z Krzysztofem Kieślowskim, Grzegorzem Królewiczem czy Tomaszem Zygadłą[20], byli bowiem przedsta-

[17] T. Lubelski, Historia kina polskiego 1895-2014, Kraków 2015, s. 304.

[18] S. Ozimek, Film dokumentalny, [w:] Historia filmu polskiego, t. VI 1968-1972, red. R. Marszałek, Warszawa 1994, s. 222.

[19] M. Jazdon, Kino dokumentalne Kazimierza Karabasza, Poznań 2009, s. 43.
[20] Do kanonu „nowej zmiany” zaliczana jest również wczesna twórczość Krzysztofa Wojciechowskiego, Krzysztofa Gradowskiego, Marka Piwowskiego, Marcela Łozińskiego, Pawła Kędzierskiego, Wojciecha Wiszniewskiego i Andrzeja Titkowa. - M. Jazdon, P. Pławuszewski, op.cit., s. 249-256. 
wicielami tak zwanego pokolenia '68. Ostatni z wymienionych twórców tak mówił o znaczeniu wydarzeń marcowych dla ich wspólnotowej tożsamości:

Łączyło nas kilka rzeczy - przede wszystkim doświadczenie Marca '68, kiedy zobaczyliśmy i odczuliśmy, że na naszych oczach dzieje się coś ohydnego. Wszyscy mieliśmy szczególny stosunek do dokumentu, byliśmy przekonani, że choć musimy grać z władzą w fałszywe karty, możemy opowiedzieć prawdę o rzeczywistości. Dla nas było to naprawdę dużo, zwłaszcza że dokument w tamtym czasie miał ogromną widownię[21].

Nie bez wpływu na artystyczną wrażliwość dokumentalistów „nowej zmiany”, pozostawały również krwawe wydarzenia Grudnia '70[22], a w późniejszym czasie także idee Młodej Kultury. Jak wykazał Andrzej Michalak, w praktyce twórczej filmowców tej formacji dostrzegalna była wyraźna zbieżność z postulatami głoszonymi przez pokrewnych im generacyjnie poetów lingwistycznych z kręgu Nowej Fali[23]. Warto w tym miejscu przypomnieć, że w noszącym znamiona pokoleniowego manifestu Świecie nie przedstawionym[24] Juliana Kornhausera i Adama Zagajewskiego młodzi literaci zarzucali powojennej literaturze ucieczkę od prezentowania prawdziwych realiów ówczesnej Polski. Wychodząc z założenia, iż ogromne połacie rzeczywistości pozostają nieopisane, postulowali potrzebę eksploracji świata we wszystkich jego aspektach. Postawa ta wiązała się z niezgodą na rozpowszechnianą ówcześnie wersję „prawdy oficjalnej”, w której nie było miejsca dla obszarów rzeczywistości niezgodnych z narzuconym odgórnie propagandowym przekazem[25].

Pokrewne oczekiwania estetyczne formułowane były przez twórców inicjujących dokumentalną „nową zmianę”. Zarzucali oni bowiem swoim dotychczasowym mistrzom konformizm i fasadowe przedstawianie rzeczywistości. Oczekiwali od dokumentu podejmowania aktualnych problemów publicystycznych i demaskowania patologii życia społecznego. Co oczywiste, dążenie do ukazania prawdziwego oblicza PRL musiało być realizowane w ramach istniejących uwarunkowań cenzuralnych. By przekazać swoją prawdę o świecie, młodzi filmowcy zmuszeni byli zastosować model opowiadania zorientowany na generowanie sensów naddanych - wykorzystując narracyjną strategię języka ezopowego, ukazywali degeneracje ówczesnej

[21] T. Zygadło, Szkoła podstawowa. Rozm. przepr. M. Sadowska, [w:] Chetmska 21. 50 lat Wytwórni Filmów Dokumentalnych i Fabularnych $w$ Warszawie, red. B. Janicka i A. Kołodyński, Warszawa 2000, s. 132. [22] Stanisław Ozimek następująco rekonstruował ciąg ich pokoleniowych doświadczeń: „Można się pokusić o roboczą diagnozę, że uczestnicy «nowej zmiany» zawarli w swej pokoleniowej, solidarnej pamięci wczesne przeżycie Października 1956, świadome Marca 1968 i dojmujące Grudnia 1970, wyrażając w swej twórczości zaangażowaną w problemy współ- czesności, dyskusyjną postawę" - S. Ozimek, op.cit., S. 249.

[23] A. Michalak, Przełom w polskim dokumencie program artystyczny „szkoły krakowskiej” w kontekście przemian kulturowych i politycznych lat 1968-1971, [w:] Kino polskie, reinterpretacje: historia - ideologia - polityka, red. K. Klejsa, E. Nurczyńska-Fidelska, Kraków 2008, s. 445.

[24] J. Kornhauser, A. Zagajewski, Świat nie przedstawiony, Kraków 1974.

[25] Ibidem. 
rzeczywistości[26]. Wzorzec ten realizowały między innymi takie filmy jak Fabryka (1970) Krzysztofa Kieślowskiego czy nagrodzona na wspomnianym wcześniej krakowskim festiwalu Szkoła podstawowa (1971) Tomasza Zygadły.

Osiągnięcie założonych celów wymagało od reżyserów „nowej zmiany" użycia odmiennych niż dotychczasowe środków artystycznego wyrazu. Ważnym elementem ich filmowego języka stała się między innymi zaczerpnięta z poetyki reportażu telewizyjnego metoda "gadających głów”. Odmienny był też ich stosunek do materii opowiadania filmowego. W przeciwieństwie do zwolenników „szkoły Karabasza” nie wahali się ingerować w rejestrowane wydarzenia. Hołdowali przekonaniu, iż - jak ujął to Marcel Łoziński - „czasami trzeba tę rzeczywistość «uruchomić», dać jej jakiś «zapłon», wyzwolić pewne istniejące w niej sytuacje - pomóc wydobyć jej ukrytą prawdę, tak trudno dostępną «obiektywnej» kamerze dokumentalnej[27]. Owocem tych artystycznych poszukiwań miała okazać się pierwsza w historii polskiego dokumentalizmu próba filmowego zmierzenia się z dziedzictwem Marca '68.

Wspomnianą wyżej strategię „uruchomienia rzeczywistości” Łoziński zastosował w zrealizowanym wraz z Pawłem Kędzierskim w 1973 roku filmie Happy end. Niespełna siedemnastominutowy obraz był dokumentalnym zapisem szkolenia odbywającego się w Centralnym Ośrodku Doskonalenia Kadr Kierowniczych w Warszawie. Po latach reżyser następująco opowiadał o motywacjach stojących za wyborem tej właśnie lokacji:

chodziło o to, żeby sfilmować zebranie partyjne jak w marcu 68, krótko mówiąc, gdzie trzeba było kogoś wyrzucić. Nie było mowy o tym, żeby wejść $\mathrm{z}$ kamerą na autentyczne zebranie partyjne, ale można było pokazać tak zwany aktyw kierowniczy, to znaczy dyrektorzy różnych fabryk, prawdziwi pracownicy ministerstw i tym podobni[28].

Wymienionych przez Łozińskiego uczestników szkolenia zaangażowano do zainscenizowania psychodramy mającej odzwierciedlać przebieg hipotetycznego zebrania załogi dużego zakładu produkcyjnego. Scenariusz zawierał jedynie szczątkowy zarys akcji[29], jej rozwój miał natomiast w dużej mierze zależeć od decyzji podejmowanych przez poszczególnych bohaterów, którym powierzono ogólnikowo nakreślone role. Ważnym elementem reżyserskiej wizji było także wprowadzenie w obręb rejestrowanej sytuacji „podstawionych” postaci, które pełniły funkcję katalizatora wyzwalającego prawdziwe poglądy i emocje osób zaangażowanych w filmowaną inscenizację. Utwór został jednak skomponowany w taki sposób, by widz dopiero na końcu dowiedział się, iż zaprezentowana historia była rodzajem psychospołecznego eksperymentu. Od pierwszych chwil seansu budowane jest bowiem

[26] M. Jazdon, P. Pławuszewski, op.cit., s. 255. [27] M. Łoziński, Trzeba odnaleźć ten jeden delikatny ton. Rozm. przepr. T. Sobolewski, „Kino” 1992, nr 8, s. 4-9.
[28] Idem, Czerpać z rzeczywistości, [w:] Debiuty polskiego kina, red. M. Hendrykowski, Konin 1998, s. 236. [29] M. Łoziński, P. Kędzierski, Młodzi kontrowersyjni (not. AK), „Film” 1973, nr 19, s. 9. 
przeświadczenie, że jesteśmy świadkami prawdziwego zebrania odbywającego się w realnie istniejącej fabryce. Całość ekranowych wydarzeń zogniskowana jest wokół postaci odpowiedzialnego za nadzorowanie procesów produkcyjnych inżyniera Koconia (w bohatera wcielił się dokumentalista Piotr Chodakowski). Szybko okazuje się, iż padł on ofiarą wewnątrzzakładowego ostracyzmu - wykazał wadliwość dużej partii wyprodukowanych w fabryce silników, co przyczyniło się do niewykonania założonego planu i pozbawienia pracowników przysługujących $\mathrm{z}$ tego tytułu premii. Oczywiste jest jednak, że wina leży po stronie dyrekcji, która zdecydowała się przerzucić całą odpowiedzialność właśnie na Koconia. Wraz z rozwojem akcji rzucane pod adresem inżyniera zarzuty w coraz większym stopniu zatracają pozory merytorycznego sporu, przemieniając się w bezpardonową nagonkę. Sytuacja gęstnieje z każdą chwilą, a oskarżenia tracą jakikolwiek związek z pierwotnym problemem. Bohaterowi zarzuca się alkoholizm, niepłacenie alimentów i pogardę dla pracowników niższego szczebla. Konflikt osiąga swoje apogeum w momencie głosowania nad losem napiętnowanego inżyniera, który zostaje niemal jednogłośnie potępiony przez swoich współpracowników. Akcja zostaje wówczas zatrzymana, a jedna z obecnych na zebraniu kobiet obwieszcza zakończenie psychodramy i prosi uczestników o podzielenie się własnymi odczuciami na temat jej rezultatów.

Łoziński wielokrotnie przekonywał, że uchwycone w Happy endzie reakcje i zachowania były reżyserowane jedynie w znikomym stopniu. Twórcy filmu ograniczyli się wyłącznie do zaaranżowania pewnej modelowej sytuacji, którą wypełniły argumenty, sposób myślenia i stan emocjonalny sportretowanych bohaterów [30]. W przeprowadzonym w 1992 roku wywiadzie prasowym reżyser tak opowiadał o zastosowanych w czasie realizacji filmu metodach „uruchamiania rzeczywistości":

nie przewidywaliśmy takiego akurat przebiegu akcji. To ludzie sami nią pokierowali. W psychodramie brali udział prawdziwi menedżerowie przemysłu, kierownicy kadr, dyrektorzy zjednoczeń, którzy podobne sytuacje, jak ta z Koconiem w roli kozła ofiarnego, przerobili już w 68 roku, i dlatego tak dobrze im szło. Role mieli rozdane tylko $\mathrm{z}$ grubsza. Jednemu powiedzieliśmy: jest pan kierownikiem wydziału, dyrektor obiecał panu za dwa lata mieszkanie. A drugiemu: jak pan wykończy tego Koconia, ma pan szansę wskoczyć na jego miejsce. I to wystarczyło. „Happy end” stał się w rezultacie naszą, spóźnioną o kilka lat, repliką na Marzec. Nie mogliśmy mówić o Żydach, ale dziś widzę, że to dobrze, że nie mówiliśmy wprost[31].

W monografii poświęconej kampanii antysyjonistycznej z lat 1967-1968 Dariusz Stola przekonuje, iż zainicjowana wówczas nagonka była zjawiskiem społecznym rządzącym się dynamiką jedynie do pewnego stopnia zależną od poczynań decydentów politycznych[32].

[30] Ibidem.

[31] M. Łoziński, Trzeba odnaleźć ten jeden delikatny ton. Rozm. przepr. T. Sobolewski..., s. 4.
[32] Tematyce tej poświęcony jest VII rozdział monografii Dariusza Stoli zatytułowany Nagonka jako zjawisko społeczne. - D. Stola, Kampania antysyjonistyczna w Polsce 1967-1968, Warszawa 200o, s. 189-206. 
Mobilizacja dużej części społeczeństwa pod hasłami kampanii nie była bowiem zwykłą, zdyscyplinowaną realizacją wytycznych idących z góry. Historyk zauważa:

W kampanii marcowej - gdy schodziła na coraz niższe szczeble zebrań powiatowych, dzielnicowych, zakładowych i wydziałowych organizacji partyjnych - zawarty był bez wątpienia spory ładunek oddolnej inicjatywy, wychodzenia poza dopuszczane formy zachowań, a nawet pewnego chaosu. Oprócz dowodów bierności i mechanicznego wykonywania obrzędów napotykamy w źródłach liczne ślady ożywienia i podniecenia. W marcowych obrzędach znajdujemy spory element improwizacji, choć była to improwizacja na temat podawany przez tubę propagandy i wykorzystująca formy wcześniej wyuczone[33].

Łoziński i Kędzierski z powodzeniem odtworzyli zatem sytuację nazwaną przez Stolę kampanijnym „obrzędem”. Wskazując swoim bohaterom kozła ofiarnego w postaci fikcyjnego inżyniera Koconia, sprowokowali ich do powtórzenia zachowań z okresu niesławnej nagonki. Gdy w 1973 roku film pojawił się na ekranach, pamięć o mechanizmach napiętnowania domniemanych syjonistów była jeszcze wystarczająco żywa, by wzbudzić w widzach skojarzenia z okresem wydarzeń marcowych. Jak trafnie ujął to Tadeusz Sobolewski: „przez chwilę powiało grozą 1968 roku, kiedy na podobnych zebraniach piętnowano «obcych»"[34].

Marcowe echa ostatniej dekady
[33] Ibidem, s. 189-190.

[34] T. Sobolewski, Marcel Łoziński (publikacja dołączona do wydanych przez Narodowy Instytut Audiowizualny płyt DVD z filmami dokumentalnymi reżysera), 2006.
Zapoczątkowana przez twórców Happy endu dokumentalna refleksja nad wydarzeniami marcowymi przez długie lata nie miała kontynuatorów. Cenzuralne tabu, jakim objęto tematy dotyczące najnowszej politycznej przeszłości kraju, było bowiem szczególnie skutecznie egzekwowane w obszarze kina dokumentalnego. W połowie lat siedemdziesiątych przekonał się o tym między innymi Krzysztof Kieślowski, gdy uniemożliwiono mu zarejestrowanie audiowizualnych wywiadów z niegdysiejszymi komunistycznymi dygnitarzami, którzy utracili polityczne wpływy na początku dekady. Projekt, który mógł okazać się niezwykle cennym dokumentalnym źródłem dotyczącym epoki gomułkowskiej, został jednak zastopowany już na bardzo wczesnym etapie[35].

Kilka lat później ciche echa Marca wybrzmiały w poetyckim dokumencie Andrzeja Brzozowskiego Hotel. Calendarium (1982, premiera 1988). Film w metaforycznej formie opowiadał o dwudziestowiecznych dziejach Polski, ukazując je przez pryzmat losów warszawskiego hotelu Bristol od momentu jego wzniesienia aż po rok 1981. W toku filmowej narracji powracały historyczne wydarzenia, których niemym świadkiem był ikoniczny budynek. Brzozowski w subtelny sposób wplótł 
w filmową opowieść pamięć o politycznych kryzysach wstrząsających życiem politycznym powojennej Polski. Ich obecność zamanifestowana została wyłącznie za pośrednictwem archiwalnych zaproszeń na odbywające się w tytułowym hotelu bale sylwestrowe. Kolejne pojawiające się na ekranie odświętne inwitacje odsyłały do szeregu nieprzypadkowych dat: 1956/1957, 1968/1969, 1970/1971. Niewygodne dla ówczesnych władz historyczne odniesienia wraz z pojawiającymi się w finale filmu nawiązaniami do aktualnej sytuacji politycznej sprawiły jednak, że Hotel. Calendarium trafił na cenzorskie półki[36].

Dopiero początki procesów liberalizacyjnych drugiej połowy lat osiemdziesiątych pozwoliły dokumentalistom na nieco odważniejszą eksplorację zakazanych tematów. Pamięć o wydarzeniach marcowych objawiła się wówczas między innymi jako poboczny wątek filmów biograficznych skoncentrowanych wokół życiorysów wybitnych postaci. W tendencję tę wpisywał się zrealizowany w 1987 roku obraz Grzegorza Królikiewicza Człowiek środka, przybliżający sylwetkę Jerzego Toeplitza - byłego rektora PWSTiF, który wyemigrował z Polski w wyniku antysemickiej nagonki roku 1968. Marcowe odniesienia pojawiły się również $\mathrm{w}$ dwóch dokumentach poświęconych biografii Stefana Kisielewskiego, które pod koniec dekady zrealizował Marian Terlecki. Powstały w 1987 roku Kisiel oraz o rok późniejszy Alfabet Kisiela do wydarzeń tamtego czasu nawiązywały w sposób anegdotyczny i niepozbawiony dystansu właściwego charyzmatycznemu bohaterowi. W roku 1988 pamięć o Marcu odżyła także w paradokumencie Marii Zmarz-Koczanowicz Sprzedawca chleba. Film opowiadał o losach należącego zarówno do PZPR, jak i do „Solidarności” dziennikarza, który po wprowadzeniu stanu wojennego zrezygnował $\mathrm{z}$ uprawianego zawodu i zajął się tytułową sprzedażą pieczywa. W otwierającej film sekwencji protagonista wraca pamięcią do przełomowych wydarzeń historii PRL, szczególną uwagę poświęcając wypadkom roku 1968. W krótkiej relacji wspomina on swoje uczestnictwo w studenckich manifestacjach, nazywając je pierwsza w jego życiu lekcją myślenia kategoriami społecznymi.

W przełomowym roku 1989 Marzec nadal pozostawał zatem dla polskiego dokumentu tematem niemalże niezbadanym i oczekującym na należyte opracowanie. Wspomniane wyżej krótkie epizody jedynie zapowiadały radykalny zwrot w dokumentalnym opowiadaniu o wydarzeniach roku 1968, który nadejść miał wraz z upadkiem reżimu komunistycznego. Wraz ze zniesieniem cenzuralnych ograniczeń Marzec niemal natychmiast stał się tematem filmów wpisujących się w popularny wówczas prąd „wybawiania białych plam” z najnowszej historii kraju, za którego symboliczny początek uznać można telewizyj-

[36] A. Brzozowski, Hotel. Calendarium, [w:] Chetmska 21. 50 lat Wytwórni Filmów Dokumentalnych $i$ Fabularnych $w$ Warszawie, red. B. Janicka, A. Kołodyński, Warszawa 2000, s. 216-227. 
ną premierę kilkuczęściowego dokumentu Marcela Łozińskiego 45-89 w roku 1990. W niespełna dziesięciominutowym fragmencie filmu reżyser zestawił ze sobą niepublikowane dotąd archiwalne nagrania Polskiej Kroniki Filmowej z roku 1968 ze wspomnieniami Jacka Kuronia i Jana Józefa Lipskiego, rozpoczynając tym samym nowy rozdział w dziedzinie filmowego opowiadania o Marcu i jego następstwach.

B I B L I O G R A F I A

Brzozowski A., Hotel. Calendarium, [w:] Chełmska 21. 50 lat Wytwórni Filmów Dokumentalnych i Fabularnych w Warszawie, red. B. Janicka, A. Kołodyński, Warszawa 2000, s. 216-227

Cieśliński M.K., Piękniej niż w życiu. Polska Kronika Filmowa 1944-1994, Warszawa 2006

Cieśliński M.K., Polska Kronika Filmowa. Podglądanie PRL-u, Warszawa 2016

Dobiega końca realizacja „Sprawiedliwych”, „Magazyn Filmowy” 1968, nr 26, s. 15

Hendrykowski M., Polska Kronika Filmowa, [w:] Historia polskiego filmu dokumentalnego (1945-2014), red. M. Hendrykowska, Poznań 2015, s. 701-725

Iskierko A., Poszukiwanie prawdy o przeszłości i dniu dzisiejszym. Wywiad z H. Jantosem, „Ekran” 1968, nr 18, s. 11

Jazdon M., Kino dokumentalne Kazimierza Karabasza, Poznań 2009

Jazdon M., Pławuszewski P., Polski film dokumentalny lat siedemdziesiątych. Nic o nas bez nas, [w:] Historia polskiego filmu dokumentalnego (1945-2014), red. M. Hendrykowska, Poznań 2015, s. 227-360

Jędrzejski Ł., Polska Kronika Filmowa w latach 1945-1968 jako medium partyjne. Zarys problemu, „Polityka i Społeczeństwo” 2017, nr 1, s. 158-170

Kidawa J., Sprawiedliwi, „Magazyn Filmowy”, 1968, nr 16, s. 15

Kidawa J., Sprawiedliwi. Świadectwo prawdy o dawnych czasach. Rozm. przepr. K. Zybert, „Ekran” 1968, nr 16, s. 2

Kieślowski K., O sobie, red. D. Stok, Kraków 1997

Kornhauser J., Zagajewski A., Świat nie przedstawiony, Kraków 1974

Lemann J., Film dokumentalny, [w:] Encyklopedia kultury polskiej XX wieku. Film kinematografia, red. E. Zajiček, Warszawa 1994, s. 199-243

Lubelski T., Historia kina polskiego 1895-2014, Kraków 2015

Łoziński M., Czerpać z rzeczywistości, [w:] Debiuty polskiego kina, red. M. Hendrykowski, Konin 1998, s. 225-239

Łoziński M., Trzeba odnaleźć ten jeden delikatny ton. Rozm. przepr. T. Sobolewski, „Kino” 1992, nr 8, s. 4-9

Łoziński M., Kędzierski P., Młodzi kontrowersyjni (not. AK), „Film” 1973, nr 19, s. 9,19

Michalak A., Przełom w polskim dokumencie - program artystyczny „szkoły krakowskiej" w kontekście przemian kulturowych i politycznych lat 1968-1971, [w:] Kino polskie, reinterpretacje: historia - ideologia - polityka, red. K. Klejsa, E. Nurczyńska-Fidelska, Kraków 2008, s. 435-446

O tym nie wolno zapomnieć, „Magazyn Filmowy” 1968, nr 31, s. 10

Ozimek S., Film dokumentalny, [w:] Historia filmu polskiego, t. VI 1968-1972, red. R. Marszałek, Warszawa 1994, s. 185-252

Pietrzak M., Wygnanie ocalonych. Doświadczenie emigracji pomarcowej w filmach Mariana Marzyńskiego i Leszka Leo Kantora, „Images. The International Journal of European Film, Performing Arts and Audiovisual Communication" 2017, nr 29, s. 137-147 
Sobolewski T., Marcel Łoziński (publikacja dołaczona do wydanych przez Narodowy Instytut Audiowizualny płyt DVD z filmami dokumentalnymi reżysera), 2006 Sprawiedliwi, „Film” 1968, nr 16, s. 2

„Sprawiedliwi” i inne filmy dokumentalne, „Film” 1968, nr 20, s. 2

Stola D., Kampania antysyjonistyczna w Polsce 1967-1968, Warszawa 2000

Zamierzenia i plany WFD, „Magazyn Filmowy” 1968, nr 20, s. 2

Zwierzchowski P., Rok 1968 w polskim kinie - konteksty i konsekwencje, [w:] Yesterday. Studia $z$ historii najnowszej. Ksiega dedykowana prof. Jerzemu Eislerowi w 65 rocznicę urodzin, red. J. Olaszek, A. Dudek, Ł. Kamiński, K. Kosiński, M. Przeperski, K. Rokicki, P. Sasanka, R. Spałek, S. Stępień, Warszawa 2017, s. 592-619

Zygadło T., Szkoła podstawowa. Rozm. przepr. M. Sadowska, [w:] Chełmska 21. 50 lat Wytwórni Filmów Dokumentalnych i Fabularnych w Warszawie, red. B. Janicka, A. Kołodyński, Warszawa 2000, s. 124-135

Żukowski T., Fantazmat „Sprawiedliwych” i film „W ciemności” Agnieszki Holland, „Studia Litteraria et Historica” 2012, nr 1, s. 1-10 